\title{
Reaction of Capsicum peppers commercialized in the Federal District to bacterial wilt
}

\author{
Maurício Rossato; ${ }^{1}$ Thais R Santiago ${ }^{2}$; Carlos Alberto Lopes ${ }^{3}$ \\ ${ }^{1}$ Universidade de Brasília (UnB), Brasília-DF, Brazil; mauriciorossato@hotmail.com; ${ }^{2}$ Embrapa Agroenergia, Brasília-DF, Brazil; thais. \\ santiago@embrapa.colaborador.br; ${ }^{3}$ Embrapa Hortaliças, Brasília-DF, Brazil; carlos.lopes@embrapa.br
}

\begin{abstract}
In Brazil, the bacterial pathogens Ralstonia solanacearum and $R$. pseudosolanacearum cause substantial losses by inducing bacterial wilt on several solanaceous crops; $R$. pseudosolanacearum is the main species associated with peppers (Capsicum sp.). To verify the bacterial wilt reaction on Capsicum peppers commercialized in the Federal District (DF), fruits of several genotypes within this genus were collected from six different fairs distributed in the satellite cities of Gama, Sobradinho and Guará. Seedlings with four true leaves derived from seeds extracted from such fruits were root inoculated with $10^{8}$ $\mathrm{CFU} / \mathrm{mL}$ with a representative isolate of $R$. pseudosolanacearum (race 1, biovar 3, phylotype I, sequevar 18). The evaluated species were: Capsicum frutescens ('pimenta-malagueta'), Capsicum baccatum var. pendulum ('pimenta-dedo-de-moça') and C. chinense ('pimenta-debode' red and yellow, 'pimenta-cumarí-do-Pará', 'pimenta-biquinho', 'pimenta-habanero' and 'pimenta-de-cheiro'). Not all species were found in all six fairs. The reaction to bacterial wilt was variable and species-dependent. From 26 evaluated genotypes, none presented an immune-like response, 10 were considered resistant and 16 susceptible based on wilt incidence (Scott-Knott, 5\%). Four Capsicum baccatum accesses were positioned in the resistant group, whereas 14 out of 18 of C. chinense were susceptible. Capsicum frutescens showed variable reactions. These results contribute to indicate cultivation of specific groups of pepper according to the presence of the pathogen in the soil.
\end{abstract}

Keywords: Ralstonia solanacearum, Ralstonia pseudosolanacearum, Capsicum sp., Capsicum chinense, Capsicum baccatum var. pendulum, Capsicum frutescens, disease resistance.

\section{RESUMO}

Reação à murcha bacteriana de pimentas Capsicum comercializadas na região do Distrito Federal

No Brasil, as espécies Ralstonia solanacearum e R. pseudosolanacearum causam perdas substanciais ao induzir a murcha bacteriana em diversas solanáceas, sendo a segunda a principal espécie associada com as pimentas (Capsicum sp.). Para verificar a reação à murcha bacteriana neste grupo de hortaliças comercializadas no Distrito Federal (DF), frutos de distintos genótipos dentro do gênero foram coletados em seis feiras distribuídas nas cidades satélites Gama, Sobradinho e Guará. Plantas com quatro folhas verdadeiras derivadas de sementes obtidas desses frutos foram inoculadas pela raiz com inóculo na concentração de $10^{8} \mathrm{UFC} / \mathrm{mL}$ de um isolado representativo de $R$. pseudosolanacearum (raça 1, biovar 3, filotipo I, sequevar 18). As espécies avaliadas foram: Capsicum frutescens ('pimenta-malagueta'), C. baccatum var. pendulum ('pimenta-dedo-de-moça') e C. chinense ('pimenta-de-bode' vermelha e amarela, 'pimenta-cumarí-do-Pará', 'pimenta-biquinho', 'pimenta-habanero'e 'pimenta-de-cheiro'). Nem todas as espécies de Capsicum foram encontradas nas seis feiras da região. A reação dos genótipos à murcha bacteriana foi variável. Dos 26 genótipos, nenhum apresentou uma resposta do tipo imune, 10 foram considerados resistentes e 16 suscetíveis, como indicado pelo agrupamento por Scott-Knott (5\%). Todos os quatro genótipos de $C$. baccatum var. pendulum foram resistentes, 14 de C. chinense foram suscetíveis e $C$. frutescens mostrou reação variável. Esses resultados contribuem para a escolha de tipos de pimentas e genótipos a serem cultivados em solos com históricos diferentes de ocorrência da murcha bacteriana.

Palavras-chave: Ralstonia solanacearum, Ralstonia pseudosolanacearum, Capsicum sp., Capsicum chinense, Capsicum baccatum var. pendulum, Capsicum frutescens, suscetibilidade, resistência a doenças.

\section{Received on April 10, 2017; accepted on February 8, 2018}

$\mathrm{P}$ eppers of the genus Capsicum are represented by many types and species, some of them very popular as a condiment in Brazil. Their use dates back from pre-Colombian American civilizations, where they were used in many recipes as component of sauces or as sole spice (Reifschneider
\& Carvalho, 2008). Nowadays, they are commercialized in several forms, especially in natura, as powders, flakes, and sauces (Moreira et al., 2006). Aside the consumption as a condiment, peppers can be used for pharmaceutical and cosmetic products, extending its use and importance (Neitzke et al., 2016).
Capsicum peppers are cultivated mainly by small farmers in approximately 5000 ha in Brazil, with a production estimated in 50,000 to 70,000 tons (Reifschneider \& Carvalho, 2008). The states of Minas Gerais, Goiás, São Paulo, Ceará, and Rio Grande do Sul are the main producers (Reifschneider 
\& Carvalho, 2008). In the Federal District, the most marketed types of pepper are Capsicum frutescens ('malagueta' pepper), C. baccatum var. pendulum ('pimenta-dedo-de-moça') and $C$. chinense ('pimenta-de-bode' vermelha e amarela, 'pimenta-cumarído-Pará', 'pimenta-biquinho', 'pimentahabanero' and 'pimenta-de-cheiro'). These peppers are preferably consumed in natura; however, they can also be processed and sold in a variety of forms. Currently, there is a growing demand in the pepper market and this has stimulated the increase of cultivated area in Brazil (Pinto et al., 2016).

The genus Capsicum presents great diversity, summing 35 taxa, considering species and varieties (Bianchetti \& Carvalho, 2005). This botanic family is notorious not only as one of the most cultivated around the world but also for suffering from many phytosanitary problems. One of them is the bacterial wilt, which can be a major constraint when susceptible genotypes are cultivated in areas subjected to high temperatures and soil moisture (Dagnoko et al., 2013). This disease is caused especially by the recently reorganized taxonomy pathogen of the $R$. solanacearum complex species, $R$. pseudosolanacearum. Previously identified as race 1 , biovar 3 , phylotype I, this pathogen has been found to be more aggressive on Capsicum than $R$. solanacearum (races 1, 2, 3, biovars 1, 2, phylotype II) (Takatsu \& Lopes, 1997; Netto et al., 2003; Lopes \& Boiteux, 2004). In addition, from the species of the complex, $R$. pseudosolanacearum is considered the one with the biggest evolving rates and larger geographic distribution in the world (Lebeau et al., 2011; Wicker et al., 2012). Even only being reported one sequevar of phylotype I (sequevar 18) in Brazil (Santiago et al., 2017), there is great diversity of hosts which isolates from this sequevar can infect. Data indicating losses caused by bacterial wilt disease in Capsicum peppers are not available, being hard to quantify them because the crops are usually conducted by small growers spread all over the country.

Due the importance of Ralstonia species as a soilborne pathogen of difficult control in the array of Capsicum spp., this work had as objective to assess the reaction to bacterial wilt disease of commonly used varieties of Capsicum peppers commercialized in natura in popular fairs in the Federal DistrictBrazil.

\section{MATERIAL AND METHODS}

\section{Capsicum genotypes acquisition}

Six fairs distributed along the Federal District in Brazil, Sobradinho, Gama and Guará, were visited for the acquisition of types and species of Capsicum peppers commercialized within the region: two fairs in each site. The selection of these fairs took into consideration their position across the Federal District, in an attempt to cover eventually different markets.

The species and types of Capsicum peppers acquired were: malagueta, dedo-de-moça, pimenta-de-bode, cumarí-do-Pará, biquinho, habanero and pimenta-de-cheiro. (Table 1). All the genotypes were bought as mature fruits where they were commercialized in natura. Seeds of these fruits were extracted manually, set to dry under shade for $48 \mathrm{~h}$ and dried in a hot air chamber for $24 \mathrm{~h}$ at $38^{\circ} \mathrm{C}$. The seeds of $C$. frutescens required dormancy breaking by pre-germinating them for 15 days in gerbox with filter paper soaked in $\mathrm{KNO}_{3}$ at $0.2 \%$ (Freitas et al., 2008). From them, seedlings were produced in 128-cell polystyrene trays with sterile substrate. After pre-germination, the $C$. frutescens seeds were transplanted to polystyrene trays and kept in greenhouse with the other species. By the time of the inoculation, all plants were 55 days old and displayed four true leaves.

Two accessions from Embrapa Hortaliças' germplasm bank were used as controls, $C$. chinense $\mathrm{CNPH}$ 3800 (resistant) and C. baccatum var. pendulum CNPH 3779 (susceptible), as indicated in previous tests with $R$. pseudosolanacearum inoculations. The controls were used to ensure the adequacy of the experiment to screen the genotypes for resistance, taking into consideration the climatic conditions, virulence of isolate, method of inoculation and inoculum concentration.

Ralstonia pseudosolanacearum isolate selection, inoculation and disease assessment

Ralstonia pseudosolanacearum isolate CNPH-RS 380 (race 1, biovar 3 , phylotype I, sequevar 18) was chosen due its high virulence response on previous experiments on Capsicum plants, and for representing the majority of $R$. pseudosolanacearum strains from the collection (data not shown). The isolate is part of the bacterial collection from Embrapa Hortaliças and was kept in cryogenic tubes in water at room temperature. For inoculum preparation, the isolate was streaked in modified Kelman medium devoid of tetrazolium chloride (Kelman, 1954) and kept in growth chamber for $48 \mathrm{~h}$ at $28^{\circ} \mathrm{C}$. Characteristic colonies with white color, fluid aspect and irregular borders, typical of the virulent type of the pathogen, were selected, re-streaked into Petri dishes with the same medium and growth conditions, and cultivated again for $48 \mathrm{~h}$ at $28^{\circ} \mathrm{C}$. The inoculum was prepared by washing the colonies from the plate with water and calibrating the concentration with a spectrophotometer for the approximate concentration of $10^{8} \mathrm{CFU} / \mathrm{mL}$, according to a previously calibrated curve.

The inoculation was performed by washing and clipping with scissors, the lower third of the root system, which was then dipped in the inoculum suspension for one minute. After inoculation, plants were transferred to $1 \mathrm{~L}$ plastic pots and kept in a greenhouse for 14 days with night heating to prevent temperature drop below $20^{\circ} \mathrm{C}$ that could increase the chance of escapes. During the experimental period, the temperature was $30 \pm 10^{\circ} \mathrm{C}$.

Disease incidence was assessed every two days and started when the first symptoms appeared, five days after inoculation on the susceptible control, by counting the number of wilted plants ( $+50 \%$ wilted leaves). The last evaluation occurred 14 days after inoculation, when the number of wilted plants stabilized.

The experiment was carried out in a completely randomized design with 
five replications of four plants each, with a total of 20 plants per treatment. This design was used based on the uniform environmental condition in the greenhouse. Statistical analysis was made by analysis of variance (ANOVA) and treatment means compared using the Scott-Knott test at 5\% of significance. Statistical analyses were conducted with the SISVAR v.5.6 (Ferreira, 2011). All experiments and practices were performed at Embrapa Hortaliças, Brasilia-DF.

\section{RESULTS AND DISCUSSION}

All fairs visited in the Federal District had Capsicum peppers for sale in natura, but not all types and species. Three species of Capsicum were consistently found, C. chinense, C.baccatum var. pendulum and $C$. frutescens (Table 1). These same species have already been indicated as the most commonly sold peppers in the Federal District (Pinto et al., 2016). The unavailability of all species and genotypes was probably due the multiregional habits of the local population, which can establish which species that are more commercialized upon demand (Henz \& Carvalho, 2008).

Even though the Federal District is a Capsicum producing region, several pepper sellers bought their products from Central de Abastecimento do Distrito Federal (CEASA-DF) which, by its turn, obtain and distribute fresh fruits and vegetables from other regions like the states of Goiás, São Paulo and Minas Gerais. Therefore, the pepper being sold are not necessarily produced close to the fair where the genotypes were bought (Pinto et al., 2016).

The pathogen inoculation was successful and the conditions were favorable for disease development, allowing the differentiation of resistance classes among genotypes. The 'dedo-demoça' type displayed the lower disease incidence mean, presenting 29\% of wilt and a variation from $20 \%$ to $35 \%$ on the three collected accesses (Figure 1). 'Malagueta' pepper had a mean of $47 \%$ incidence on five genotypes (15\% to $82 \%$ ); red 'pimenta-de-bode', with mean of $51 \%$ incidence but also with large variation among the five genotypes (10\% to $78 \%$ ); 'pimenta-de-cheiro' with $64 \%$ (40 to $84 \%$ ); 'habanero' with 75\%; 'biquinho' with 95\%; and yellow 'pimenta-de-bode' with 45\% (36\% to $55 \%$ ). A small number (five out of 26) of the accesses had similar or higher susceptibility in comparison to the susceptible control (CNPH 3779): one 'malagueta', one red 'pimenta-debode', one 'pimenta-de-cheiro', one 'cumarí-do-Pará', and one 'biquinho'. Comparing with the resistant control (CNPH 3800), only three out of the 26 genotypes had the same level of resistance: one 'dedo-de-moça', one 'malagueta', one red 'pimenta-de-bode'.
The Scott-Knott analysis differentiated two groups of resistance: a resistant group, made of 10 accesses of all three species of Capsicum that grouped with the resistant control (CNPH 3800), and a susceptible group, made of 16 genotypes from the three species, grouping with the susceptible control (CNPH 3779) (Figure 1).

Considering the reaction of each Capsicum species, the average wilt incidence of C. baccatum var. pendulum was $23.3 \%, C$. chinense of $63.2 \%$ and C. frutescens of $47.4 \%$, indicating a tendency that species react differently to bacterial wilt induced by $R$. pseudosolanacearum. 'Dedo-de-moça' showed the larger number of resistant

Table 1. List of 26 Capsicum genotypes of three species (Capsicum baccatum var. pendulum, C. chinense and C. frutescens) and eight genotypes acquired in natura in six different vegetable fairs in the region of Federal District-Brazil. The ' $\mathrm{X}$ ' identified in which region the genotype was bought. Brasilia, Embrapa Hortaliças, 2008.

\begin{tabular}{|c|c|c|c|c|}
\hline Species & Pepper type & obradinho & Gama & Guará \\
\hline \multirow{3}{*}{$\begin{array}{l}\text { Capsicum baccatum } \\
\text { var. pendulum }\end{array}$} & 'Dedo-de-moça'1 & & & $\mathrm{X}$ \\
\hline & 'Dedo-de-moça'2 & & & $\mathrm{X}$ \\
\hline & 'Dedo-de-moça'3 & & $\mathrm{X}$ & \\
\hline \multirow{18}{*}{ Capsicum chinense } & 'Pimenta-de-bode' red 1 & $\mathrm{X}$ & & \\
\hline & 'Pimenta-de-bode' red 2 & & $\mathrm{X}$ & \\
\hline & 'Pimenta-de-bode' red 3 & & & $\mathrm{X}$ \\
\hline & 'Pimenta-de-bode' red 4 & & & $\mathrm{X}$ \\
\hline & 'Pimenta-de-bode' red 5 & & $\mathrm{X}$ & \\
\hline & 'Pimenta-de-bode' yellow 1 & & $\mathrm{X}$ & \\
\hline & 'Pimenta-de-bode' yellow 2 & & $\mathrm{X}$ & \\
\hline & ‘Biquinho’' & & & $\mathrm{X}$ \\
\hline & 'Cumarí-do-Pará' 1 & & & $\mathrm{X}$ \\
\hline & ‘Cumarí-do-Pará’ 2 & & $\mathrm{X}$ & \\
\hline & ‘Cumarí-do-Pará' 3 & & & $\mathrm{X}$ \\
\hline & 'Cumarí-do-Pará' 4 & & & $\mathrm{X}$ \\
\hline & 'Pimenta-de-cheiro' 1 & $\mathrm{X}$ & & \\
\hline & 'Pimenta-de-cheiro' 2 & $\mathrm{X}$ & & \\
\hline & 'Pimenta-de-cheiro' 3 & $\mathrm{X}$ & & \\
\hline & 'Pimenta-de-cheiro' 4 & $\mathrm{X}$ & & \\
\hline & 'Habanero' 1 & & & $\mathrm{X}$ \\
\hline & 'Habanero' 2 & & $\mathrm{X}$ & \\
\hline \multirow{5}{*}{ Capsicum frutescens } & 'Malagueta' 1 & $\mathrm{X}$ & & \\
\hline & 'Malagueta' 2 & $\mathrm{X}$ & & \\
\hline & 'Malagueta' 3 & & $\mathrm{X}$ & \\
\hline & 'Malagueta' 4 & & & $\mathrm{X}$ \\
\hline & 'Malagueta' 5 & & $\mathrm{X}$ & \\
\hline
\end{tabular}




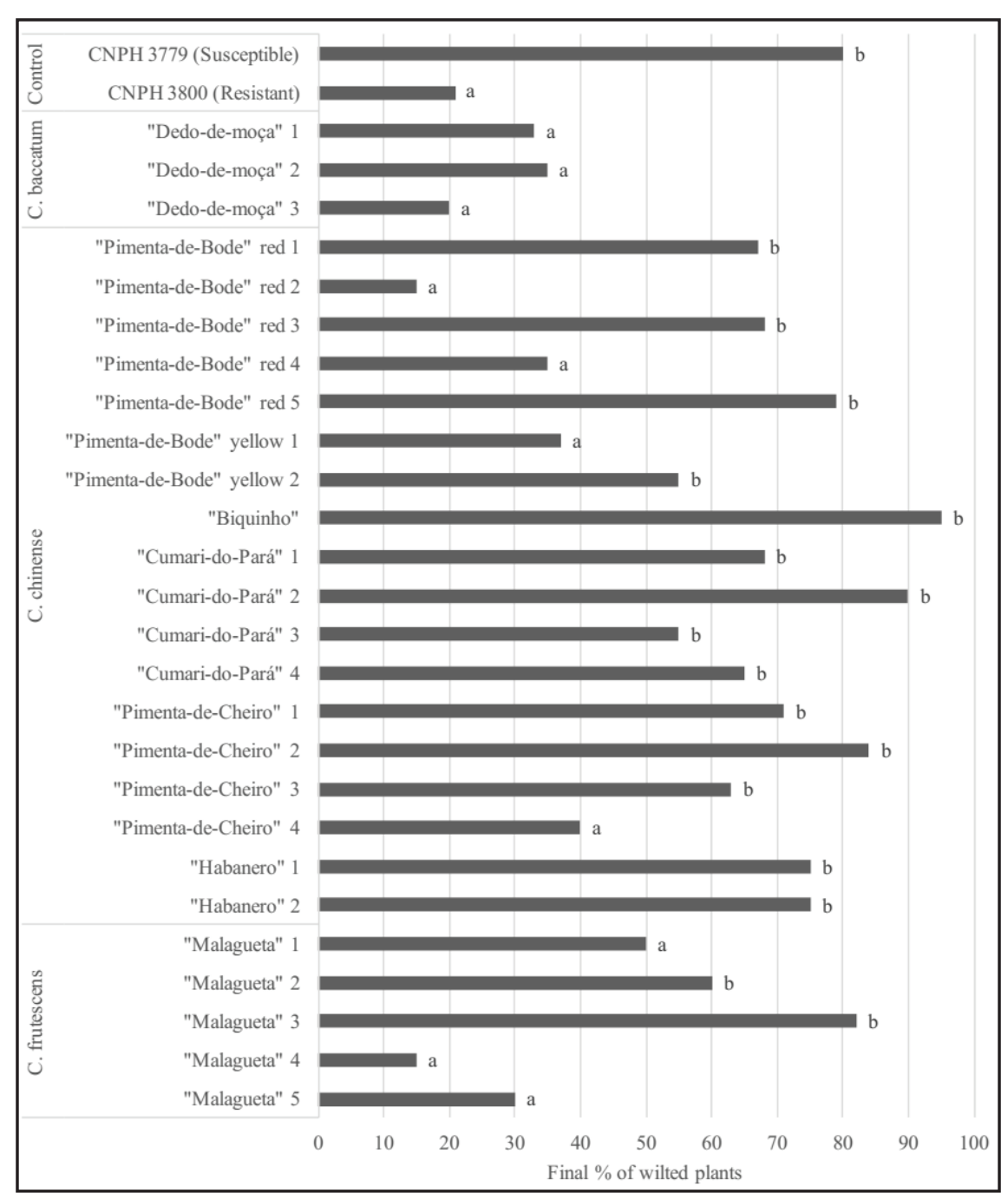

Figure 1. Percentage of wilt from the 26 Capsicum genotypes from three species collected from three popular fairs in the Federal District-Brazil, inoculated with isolate CNPH-RS 380 of Ralstonia pseudosolanacearum. Genotypes with 'a' are resistant, 'b' are susceptible (ScottKnott 5\%). Experiment with the Capsicum fruits acquired were carried out in Embrapa Hortaliças located in Gama, Federal District-Brazil in 2008. Brasilia, Embrapa Hortaliças, 2008.

genotypes, with all accessions grouping with the resistant control (CNPH 3800), while the most susceptible was 'cumarído-Pará' with all four grouping with the susceptible control (CNPH 3779). In another study, Matsunaga et al. (2011) evaluated 41 genotypes of Capsicum for their resistance to bacterial wilt and found a total of 18 highly resistant (11 C. annuum, six C. frutescens and one $C$. chinense), 17 moderately resistant (five C. annuum, 11 C. frutescens and one $C$. chinense), and only six as susceptible (C. annuum). Unless C. baccatum, which was not evaluated, the rest of the genotypes were consistent with our data, where a variable number in each and fruit size and shape, even within the same pepper type, indicates a great phenotypic variability. The diversity in Capsicum could be explained by its mix reproductive capacities, being located among autogamous and allogamous plants (do Rêgo et al., 2012) with high rates of allogamy ( $2 \%$ to $90 \%$ ) due to pollinating insects (Bosland et al., 2012). Another factor that could explain such diversity is the involuntary or intentional selection made by growers, which extract their own seeds from pepper plants for crop renewal. The variety of characteristics and resistance found among the collected genotypes present potential of use on breeding programs, especially those focused on developing bacterial wilt resistant Capsicum cultivars.

The non-use of cultivars by growers might be partially because of the lack of knowledge of available commercial seeds. For example, several cultivars of Capsicum peppers display different levels of resistance to bacterial wilt as evaluated along the breeding process at Embrapa in the past years, upon release of cultivars like BRS Ema $(C$. annuиm var. annuиm), BRS Jandaia ( $C$. chinense) and BRS Juruti (C. chinense) (Embrapa, 2014). Although complete resistance has not been achieved, their level of quantitative resistance diverges according to the species of $R$. solanacearum (biovar 1, phylotype II) and $R$. pseudosolanacearum (biovar 3, phylotype I). The use of resistant cultivars is interesting due low cost, control efficiency and minor environmental damage (Dodds \& Rathjen, 2010), especially when compared to other techniques focused on controlling the disease after the pathogen's establishment.

In conclusion, we found that there are differences in resistance to bacterial wilt, caused by $R$. pseudosolanacearum among species and within genotypes of Capsicum peppers sold in fairs in the Federal District. This information is useful for growers to decide which Capsicum type and genotype can be grown in his farm according to the level of soil infestation with the pathogen, as indicated by the presence of bacterial wilt in previous years and the crop 
rotation used, in an integrated control approach.

\section{REFERENCES}

BIANCHETTI, LB; CARVALHO, SIC. 2005. Subsídios à coleta de germoplasma de espécies de pimentas e pimentões de gênero Capsicum (Solanaceae). In: WALTER, BMT; CAVALCANTI, TB (eds). Fundamentos para a coleta de germoplasma vegetal. Brasília: Embrapa Recursos genéticos e Biotecnologia. p.355-385.

BOSLAND, PW; VOTAVA, EJ; VOTAVA, EM. 2012. Peppers: vegetable and spice capsicums. Cabi. 230p.

DAGNOKO, S; YARO-DIARISSO, N; SANOGO, PN; ADETULA, O; DOLO-NANTOUMÉ, A; GAMBY-TOURÉ, K; TRAORÉ-THÉRA, A; KATILÉ, S; DIALLO-BA, D. 2013. Overview of pepper (Capsicum spp.) breeding in West Africa. African Journal of Agricultural Research 8: 1108-1114.

DO RÊGO, ER; NASCIMENTO, MF; NASCIMENTO, NFF; SANTOS, RMC; FORTUNATO, FLG; RÊGO, MM. 2012. Testing methods for producing self-pollinated fruits in ornamental peppers. Horticultura Brasileira 30: 669-672.

DODDS, PN; RATHJEN, JP. 2010. Plant immunity: towards an integrated view of plant-pathogen interactions. Nature Reviews Genetics 11: 539-548.

EMBRAPA. 2014. Cultivares da Embrapa Hortaliças (1981-2013). Brasil: Embrapa. $182 \mathrm{p}$.

FERREIRA, DF. 2011. Sisvar: a computer statistical analysis system. Ciência e Agrotecnologia 35:1039-1042.

FREITAS, RA; NASCIMENTO, WM;
CARVAlHO, SIC. 2008. Produção de sementes. In: RIBEIRO, CSC; LOPES, CA; CARVALHO, SIC; HENZ GP; REIFSCHNEIDER, FJB (eds). Pimentas - Capsicum. Brasília: Embrapa Hortaliças. p.11-14.

HENZ, GP; CARVALHO, CSC. 2008. Mercado e comercialização. In: RIBEIRO, CSC; LOPES, CA; CARVALHO, SIC; HENZ, GP; REIFSCHNEIDER, FJB. (eds). Pimentas - Capsicum. Brasília: Embrapa Hortaliças.p.11-14.

KELMAN, A. 1954. The relationship of pathogenicity in Pseudomonas solanacearum to colony appearance on a tetrazolium medium. Phytopathology 44: 693-695.

LEBEAU, A; DAUNAY, MC; FRARY, A; PALLOIX, A; WANG, JF; DINTINGER, J; CHIROLEU, F; WICKER, E; PRIOR, P. 2011. Bacterial wilt resistance in tomato, pepper, and eggplant: genetic resources respond to diverse strains in the Ralstonia solanacearum species complex. Phytopathology 101: 154-165.

LOPES, CA; BOITEUX, LS. 2004. Biovarspecific and broad-spectrum sources of resistance to bacterial wilt (Ralstonia solanacearum) in Capsicum. Crop Breeding and Applied Biotechnology 4: 350-355.

LOPES, CA; CARVALHO, SIC; BOITEUX, LS. 2005. Search for resistance to bacterial wilt in a Brazilian Capsicum germplasm collection. In: ALLEN, C; PRIOR, P; HAYWARD, AC (eds). Bacterial wilt disease and the Ralstonia solanacearum species complex. Estados Unidos: APS Press. p.247-251.

MATSUNAGA, H; SAITO, T; SAITO, A. 2011. Evaluation of resistance to bacterial wilt and phytophthora blight in Capsicum genetic resources collected in Myanmar. Journal of the Japanese Society for Horticultural Science 80: 426-433.

MOREIRA, GR; CALIMAN, FRB; SILVA, DJH;
RIBEIRO, CSC. 2006. Espécies e variedades de pimenta. Informe Agropecuário 27: 16-29.

NEITZKE, RS; FISCHER, SZ; VASCONCELOS, CS; BARBIERI, RL; TREPTOW, RO. 2016. Ornamental peppers: acceptance and preferences by consumers. Horticultura Brasileira 34:102-109.

NETTO, RAC; PEREIRA, BG; NODA, H; BOHER, B. 2003. Caracterização de isolados de Ralstonia solanacearum obtidos de tomateiros em várzea e em terra firme, no Estado do Amazonas. Fitopatologia Brasileira 28: 362-366.

PINTO, CM; SANTOS, IC; ARAUJO, FF; SILVA, TP. 2016. Pepper Importance and Growth (Capsicum spp.). In: RÊGO, ER; RÊGO, MM; FINGER, FL (eds). Production and breeding of chilli peppers (Capsicum spp.) Springer International Publishing. p.1-25.

REIFSCHNEIDER, FJB; CARVALHO, CSC. 2008. Cultivo. In: RIBEIRO, CSC; LOPES, CA; CARVAlHO, SIC; HENZ, GP; REIFSCHNEIDER, FJB (eds). Pimentas - Capsicum. Brasília: Embrapa Hortaliças. p.11-14.

SANTIAGO, TR; LOPES, CA; CAETANO ANOLLÉS, G; MIZUBUTI, ESG. 2017. Phylotype and sequevar variability of Ralstonia solanacearum in Brazil, an ancient center of diversity of the pathogen. Plant Pathology 66: 383-392.

TAKATSU, A; LOPES, CA. 1997. Murcha bacteriana em hortaliças: avanços científicos e perspectivas de controle. Horticultura Brasileira 15: 170-177.

WICKER, E; LEFEUVRE, P; CAMBIAIRE, JC; LEMAIRE, C; POUSSIER, S; PRIOR, P. 2012. Contrasting recombination patterns and demographic histories of the plant pathogen Ralstonia solanacearum inferred from MLSA. The ISME Journal 6: 961-974. 